\title{
Material Modelling of Pare rock mass by Finite Element Back Calculation Technique
}

\author{
Pawan Kumar Singh, Diganta Goswami², Ranjeet Bahadur Singh ${ }^{3}$, Pragati Goswami ${ }^{4}$, Sylvia Kashyap $^{5}$ \\ 12345 Assam Engineering College \\ Department of Civil Engineering, Assam Engineering College, Guwahati 781013, Guwahati, India \\ singhpawank123@gmail.com, digantagoswami.ce@aec.ac.in, rbsinghntpc@gmail.com, pragatigoswami900@gmail.com, \\ sylvia.kashyap@gmail.com
}

\begin{abstract}
River Valley Projects possess great significance for the development of developing countries. They are used for various purposes like irrigation, hydroelectricity generation, water supply, flood control etc. In this regard the determination of the properties of the rock mass of the site becomes essential, which can be done with the help of in-situ tests as well as laboratory tests. But, conducting a greater number of in-situ tests in the field is not feasible, forcing one to use the tools like Finite element codes like Plaxis 3D AE for determining the properties of the rock mass. In this research work, an attempt has been made to derive the properties of the rock mass by back calculation technique using the results of In-situ Plate load test. An appropriate material modelling is very important in any Finite Element analysis to arrive at solutions close to the exact values, necessitating the selection of appropriate constitutive model. In this context, the suitability of the four constitutive models viz. Jointed Rock mass model, Hoek-Brown model, Mohr-coulomb model and Hardening Soil model, appropriate to Pare Rock mass is examined. Through this study, a systematic approach has been adopted for the simulation of rock mass properties of the Pare Hydroelectric Project site with the help of numerical modelling.
\end{abstract}

Keywords: Pare Hydroelectric Project, Plate load test, Finite Element Method, Back Calculation Technique, Root Mean Square Error

\section{Introduction}

The demand for power in India is rapidly increasing due to development requirements and so also the construction of more hydroelectric power projects. Construction of the various components of a river valley project tend to create instability in the rock mass, which is often water charged too, primarily due to alteration of in-situ stress conditions. For a safe design and execution of these elements, the behaviour of the geo-material involved, namely the rock mass, needs to be understood thoroughly and predicted well. As most of the hydro-electric power projects of India are in the Himalayan region and many more are likely to come up in this region, the behaviour of the Himalayan rock mass, with respect to construction of their various components such as dam foundation, powerhouse cavern, Headrace tunnels, surge shaft etc., needs to be understood and predicted with higher confidence level. In-situ tests like Plate load test, Tri-axial shear test, Direct shear test etc. represent the properties in a more sophisticated way than the other methods. However, multiple numbers of tests requires more resources which becomes an economic restrain, as the resources available are limited [1]. Further, the zone of influence in case of plate load test is limited only to a minimum depth from the top surface of rock formation. Therefore detailed evaluation of design models of the site cannot be made from this limited number of test results, encouraging the geotechnical engineers to go for numerical modelling or forces them to develop empirical correlations [2]. Back analyses are also often needed to be carried out to ascertain appropriate rock mass parameters like deformation modulus, sub-grade modulus, poisson's ratio etc. The deflection profile is often taken into account in the determination of the in-situ elastic modulus while performing back calculation analysis [3].Singh \&Geol (2011) [4] states that repeated cycles of back analysis and forward analysis eliminates many uncertainties in understanding the rockmass behaviour. The results obtained from back calculation techniques may differ depending on the assumptions, methods, and material models considered in the study [5]. So, a combination of forward calculation and backward analysis, from the field instrumented data capturing the actual field behaviour, during construction needs to be incorporated, to arrive at some practically correct geo-material properties. Inspite of the fact that the soil mass is highly heterogeneous, the notion of a single soil model to accurately predict the soil behaviour seems to be inappropriate [6]. 


\section{The Study Area}

The present study has been carried out at the site of the proposed Pare hydroelectric project across Pare River situated in Papum Pare district in Arunachal Pradesh. The project has been proposed to generate about $110 \mathrm{MW}$ of power in a power house, which will be produced with the help of a tunnel supplying a combined discharge of 180 cumecs from Pare and Ranga Nadi Hydro Electric Project - Stage I. The area of the Power project is represented by upper Siwalik sub-group of the sub-Himalaya range. The location of Pare Hydro-Electric Power Project (H.E.P) has been shown in figure 1.

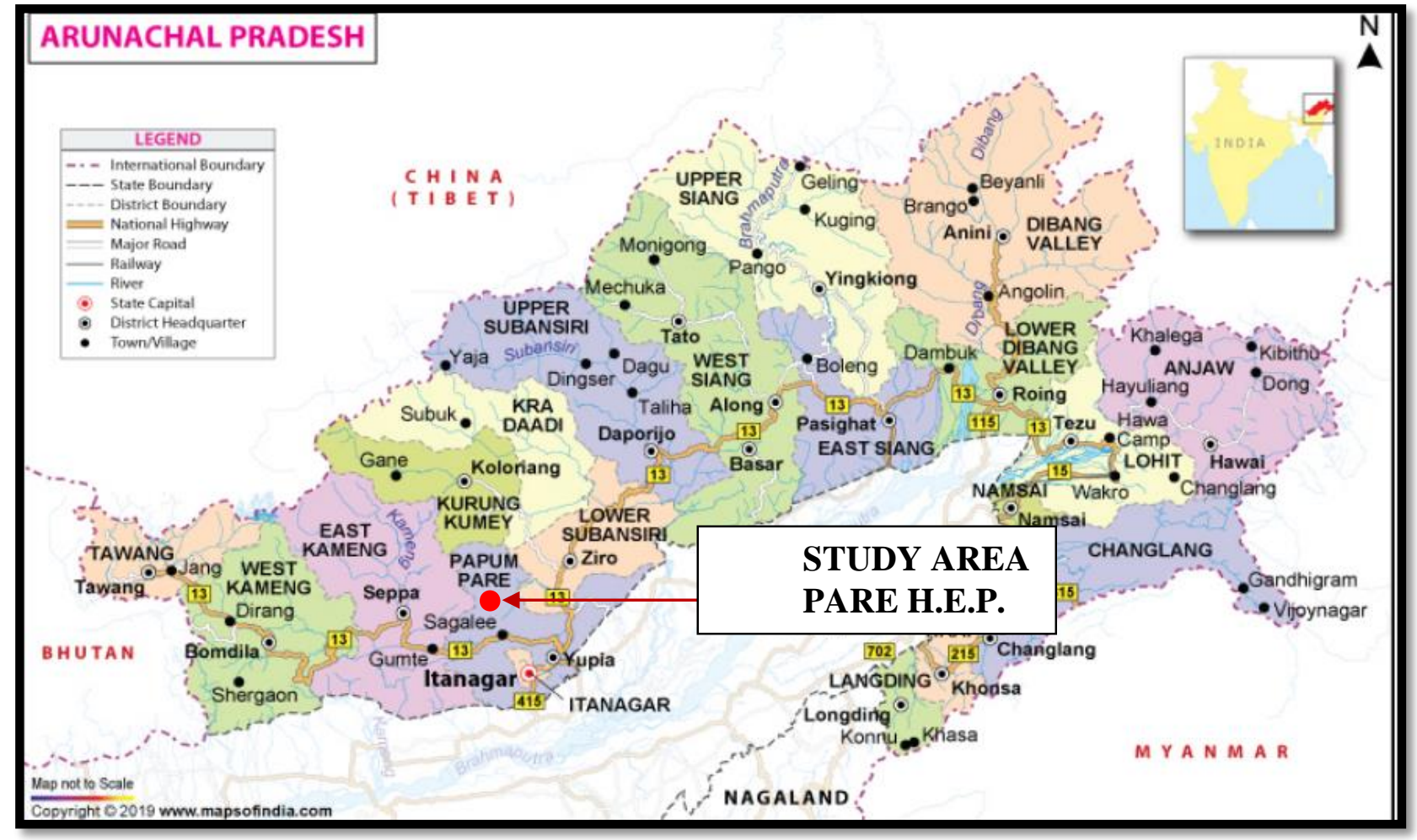

Fig. 1: Location of Pare Hydro-Electric Power Project, Pare, Arunachal Pradesh, India (Maps of India, 2019)

\section{Methodology}

The aim of the work is to simulate the observed site results of plate load test with the results obtained from the finite element method using different soil models in PLAXIS 3D AE. The characteristic of soil profiles and soil parameters are identified from field and laboratory tests. The back calculation was done by using PLAXIS 3D AE. The MohrCoulomb Model, Hoek and Brown Soil Model, Hardening Soil Model and Jointed Rock Model are used as a material model for simulation. At last the results obtained from PLAXIS 3D AE were compared with those obtained from field data using numerous trial and error procedure to get the material properties of the Pare rock mass.

\section{Geological and Geotechnical studies}

The rocks site of Upper Siwalik formation mostly has sandstone. The geological profile at the rocks of Upper Siwalik formation comprises of repetitive sequence of soft, friable, medium grained, brownish, greenish and grey colored, moderately jointed, profusely current bedded, salt-pepper textured sandstone, pebble sandstone and pebble beds with minor silt partings occur in the project area[7]. Highly overburden in rocks have been observed in the HRT alignment, surge shaft, penstock and power house areas. 
To determine the geo-mechanical properties of the test conducted area, different types of field and laboratory tests including Plate load test, petrographic measures, In situ direct shear test, and unconfined compressive strength test were carried out.

\subsection{Laboratory tests and Field tests}

The shear strength parameters $(\mathrm{C}$ and $\Phi)$ has been obtained with the help of the laboratory tests viz. Unconfined Compression test (Saturated condition), Triaxial test for the samples collected from the dam site and In situ Direct shear test for rock to rock interface at the dam site. However, it is emphasized that presence of local discontinuities /weaker zones such as fissures, fractures and joints, faults if any, within the foundation area, are to be taken into due consideration while judiciously adopting shear strength parameters and other derived quantities from the in-situ tests for design. The average of the values of angle of internal friction and cohesion as obtained from various laboratory and field tests corresponding to Pare rock mass have been presented in table 1 and 2 respectively.

Table 1: Average Value of cohesion 'C' at Pare H.E.P Site

\begin{tabular}{|c|c|c|c|}
\hline Sl. No. & Parameter & Type of Test & Value $\left(\mathrm{kN} / \mathrm{m}^{2}\right)$ \\
\hline 1 & \multirow{6}{*}{$\mathrm{C}$} & Tri axial test (UU) & 115 \\
\hline 2 & & In-situ Shear test & 121.7 \\
\hline 3 & & Unconfined compression test & $141,144,148,144,129$ (Five Readings) \\
\hline 4 & & Unconfined compression test & $104,148,164,142,148$ (Five Readings) \\
\hline 5 & & Tri axial test & 76,88 (Two Readings) \\
\hline 6 & & Tri axial test & 151 \\
\hline \multicolumn{3}{|c|}{ Average value of Cohesion (C) } & 131.6 \\
\hline
\end{tabular}

Table 2: Average Value of Angle of Internal Friction ( $\Phi)$ at Pare H.E.P Site

\begin{tabular}{|c|c|c|c|}
\hline $\begin{array}{l}\text { Sl. } \\
\text { No. }\end{array}$ & Parameter & Type of Test & Value \\
\hline 1 & \multirow{6}{*}{$\Phi$} & Tri axial test(UU) & $43.64^{\circ}$ \\
\hline 2 & & In-situ Shear test & $49.92^{\circ}$ \\
\hline 3 & & Unconfined compression test & $50^{\circ}, 48^{\circ}, 52^{\circ}, 48^{\circ}, 68^{\circ}$ (Five Readings) \\
\hline 4 & & Unconfined compression test & $32^{\circ}, 48^{\circ}, 52^{\circ}, 54^{\circ}$ (Four Readings) \\
\hline 5 & & Tri axial test & $51^{\circ}, 46^{\circ}$ (Two Readings) \\
\hline 6 & & Tri axial test & $48^{\circ}$ \\
\hline \multicolumn{3}{|c|}{ Average value of Angle of internal friction $(\Phi)$} & $49.64^{\circ}$ \\
\hline
\end{tabular}

\subsubsection{Plate load tests}

The load-settlement curve from two plate load tests conducted at two locations at Pare is shown in figure 2. The Plate load test was conducted following the guidelines mentioned in IS 1888-1982 [8], for the proposed Pare H.E. Project at Dam axis. The vertical load was applied on the test plate (Plate dimension $0.45 \mathrm{~m}$ x $0.45 \mathrm{~m}$, thickness $25 \mathrm{~mm}$ ) by means of a hydraulic jack against rolled steel joist capable of providing reaction and the settlement was recorded by means of two dial 
gauges of $0.01 \mathrm{~mm}$ sensitivity each positioned on either side of the plate and held by datum bars resting on immovable support on either side of the plate. The design load was estimated to be about5883.99 kN/sqm. Water table was not encountered at the site and so the surface was kept saturated by artificial submergence.

It is observed from figure 2 that, with the increase in load, the increase in settlement is not proportional, rather the of settlement decreases with the rate of increase of load. This is possible only when the material is gaining in strength the increase in the load. There may be closure of micro-cracks in the rock mass for which it exhibits a trend as obtained these load-settlement curves.

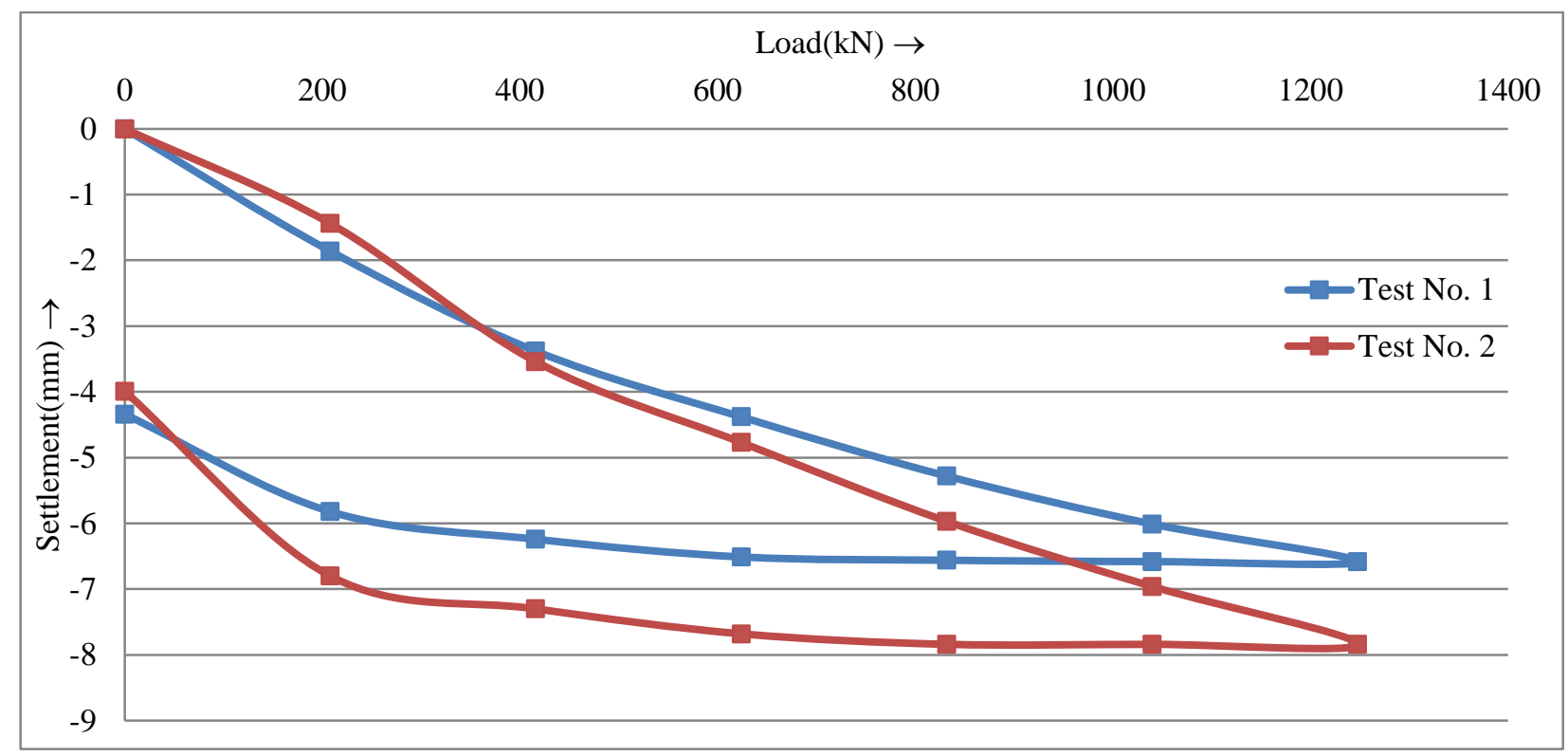

Fig. 2: Load-Settlement Curve corresponding to Field Plate Load Test

\section{Numerical Modelling}

The simulation of Plate load test with field reports are based on FEA, which has been incorporated using PLAXIS 3D AE. The dimension of the three dimensional model has been taken as $8 \mathrm{~m} \mathrm{X} \mathrm{8m} \mathrm{with} \mathrm{a} \mathrm{depth} \mathrm{of} 10 \mathrm{~m}$, so that the boundary effect is negligible. The finite element model of the Plate load test is shown in figure 2 . The parameters of soil have been taken out from the field and laboratory tests. 15 noded element is used for the model. The rock mass domain is discretised by 10 noded-tetrahedral element. The domain has been meshed with 10 noded tetrahedral element with medium coarseness. This element gives rise to a parabolic interpolation of displacements.

Steel plate is modelled as an elastic element. The size of steel plate is taken as $450 \mathrm{mmX} 450 \mathrm{~mm}$ with $25 \mathrm{~mm}$ thickness. Two dimensional six noded triangular element is used to mesh the plate. The plate is meshed as plate elements with modulus of elasticity, Esteel $=2 \times \mathrm{E} 8 \mathrm{kN} / \mathrm{m} 2$, Poisson's ratio, $\nu=0.3$, Unit weight, $\gamma=78 \mathrm{kN} / \mathrm{m} 3$.

Point load is applied vertically on the plate. Self-weight of the plate is also considered for simulation process. External load system is increased in a gradual manner and is allowed to rebound by reducing the load from phase to phase in each cycle. The analysis consists of 5 cycle.

The FEM analysis of Plate load test is modelled with a number of simulations by changing the values of the soil parameters C, $\Phi$, and E. Some of the values of elastic modulus is collected from the back calculation of the plate load test by trial-error method. The aim of the simulation process is to compare the results obtained from both the FEA and the field test.

Table 3 shows the material properties of the rock mass corresponding to different soil models used for simulation. The material properties of the model which best matches with the field plot have been presented in table 3 . 

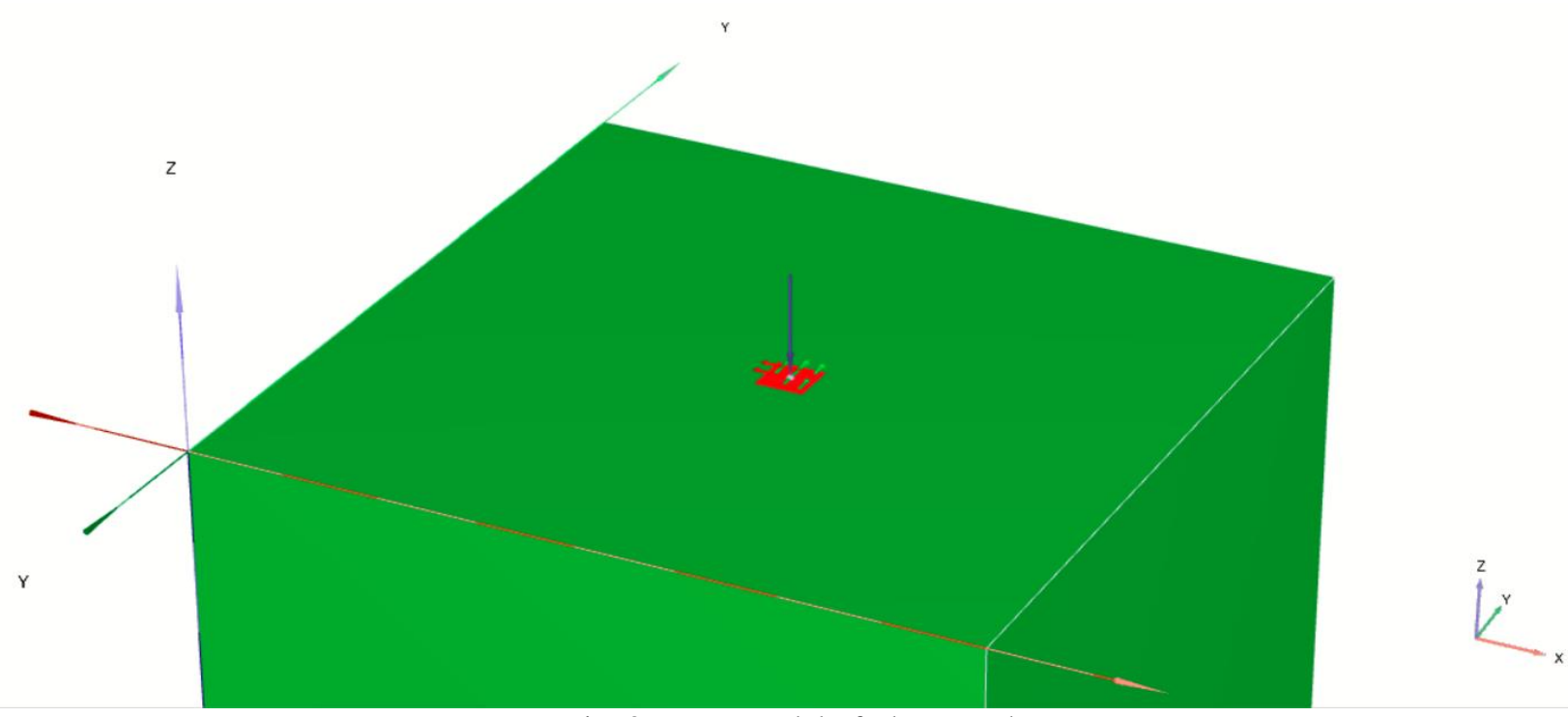

Fig. 3: FEM Model of Plate Load Test

Table 3: Physical and Mechanical properties of the rock mass corresponding to the soil models for Finite Element Modelling

\begin{tabular}{|c|c|c|c|c|c|}
\hline SI No. & Geomaterial modelling & Mohr Coulomb Model & Hoek - Brown Model & Jointed Rock Model & Hardening Soil Model \\
\hline 1 & Drainage type & Drained & Drained & Drained & Drained \\
\hline 2 & $\gamma_{\text {unsat }}\left(\mathrm{kN} / \mathrm{m}^{3}\right)$ & 17.542 & 17.542 & 17.542 & 17.542 \\
\hline 3 & $\gamma_{\mathrm{sat}}\left(\mathrm{kN} / \mathrm{m}^{3}\right)$ & 20.44 & 20.44 & 20.44 & 20.44 \\
\hline 4 & $\mathrm{e}$ & 0.422 & 0.422 & 0.422 & 0.422 \\
\hline 5 & $v^{\prime}$ & 0.2 & 0.25 & 0.2 & 0.2 \\
\hline 6 & $\mathrm{E}_{50} \mathrm{ref}\left(\mathrm{kN} / \mathrm{m}^{2}\right)$ & $3 \times E 5$ & $2.7 \mathrm{xE} 5$ & $3 \times E 5$ & $3 x E 5$ \\
\hline 7 & $E_{\text {oedref }}\left(\mathrm{kN} / \mathrm{m}^{2}\right)$ & - & - & - & $3 \mathrm{xE} 5$ \\
\hline 8 & $\mathrm{E}_{\text {urref }}\left(\mathrm{kN} / \mathrm{m}^{2}\right)$ & - & - & - & 2xE6 \\
\hline 9 & $\mathrm{C}_{\mathrm{ref}}\left(\mathrm{kN} / \mathrm{m}^{2}\right)$ & 131.6 & - & 105.3 & 131.6 \\
\hline 10 & $\Phi$ & 49.64 & - & $49.6^{0}$ & $49.64^{0}$ \\
\hline 11 & $\Psi$ & $0^{0}$ & $60^{0}$ & $0^{0}$ & - \\
\hline 12 & $\mathrm{~K}_{\mathrm{onc}}$ & - & - & - & 0.2569 \\
\hline 13 & $\mathrm{P}_{\mathrm{ref}} \mathrm{kN} / \mathrm{m}^{2}$ & - & - & - & 100 \\
\hline 14 & $Z_{\text {ref }}$ & 0 & - & - & 0 \\
\hline 15 & $\sigma \mathrm{kN} / \mathrm{m}^{2}$ & - & 1500 & - & 0 \\
\hline 16 & $\mathrm{C}^{\prime}{ }_{\text {inckN/m}} / \mathrm{m}^{2}$ & 0 & - & - & 0 \\
\hline 17 & $\mathrm{~m}_{\mathrm{i}}$ & - & 21 & - & 1 \\
\hline 18 & GSI & - & 90 & - & - \\
\hline 19 & $\mathrm{D}$ & & 0 & - & - \\
\hline 20 & $\mathrm{G}_{2}\left(\mathrm{kN} / \mathrm{m}^{2}\right)$ & - & - & $1.8 \mathrm{xE} 5$ & - \\
\hline 21 & $\alpha_{1}$ & - & - & $\begin{array}{l}40^{0} \text { (Plane 1) } \\
40^{0} \text { (Plane 2) } \\
45^{0} \text { (Plane 3) }\end{array}$ & - \\
\hline 22 & $\alpha_{2}$ & - & - & $\begin{array}{l}\left.110^{\circ} \text { (Plane } 1\right) \\
\left.150^{\circ} \text { (Plane } 2\right) \\
\left.160^{\circ} \text { (Plane } 3\right)\end{array}$ & - \\
\hline
\end{tabular}

Note: $\gamma_{\text {unsat }}$ - Unsaturated unit weight ; $\gamma_{\text {sat }}$ - Unsaturated unit weight; e - Void ratio; $v^{\prime}$ - Poisson's ratio for unloading / reloading; E50 ref - Secant stiffness in standard drained Triaxial test; $E_{o e d r e f}$ - Tangent stiffness for Primary Oedometer loading; Eurref - Unloading/ 
reloading stiffness from drained triaxial test; $\mathrm{C}_{\text {ref }}$ - (Effective) cohesion; $\Phi$ - (Effective) angle of internal friction; $\Psi$ - Dilatency angle; $\mathrm{K}_{\text {onc }}-\mathrm{K}_{\mathrm{o}}$-value for normal value of consolidation; $\mathrm{P}_{\text {ref- }}$ Reference stress for stiffnesses ; $\sigma \quad$ - Effective vertical stress; $\mathrm{m}_{\mathrm{i}} \quad$ - Intact rock parameter; GSI - Geological Strength Index; D - Disturbance factor; $\mathrm{G}_{2}-$ Shear modulus perpendicular on 'Plane 1' direction; $\alpha_{1}$ Dip; $\alpha_{2}$ - Strike.

\section{Results}

The experimental load-settlement curves obtained from Plate load test are compared with the numerical results obtained using the constitutive models viz. Mohr-coulomb model, Hoek-Brown model, Jointed Rock model and Hardening soil model as shown in the figures $4,5,6$ and 7 respectively.

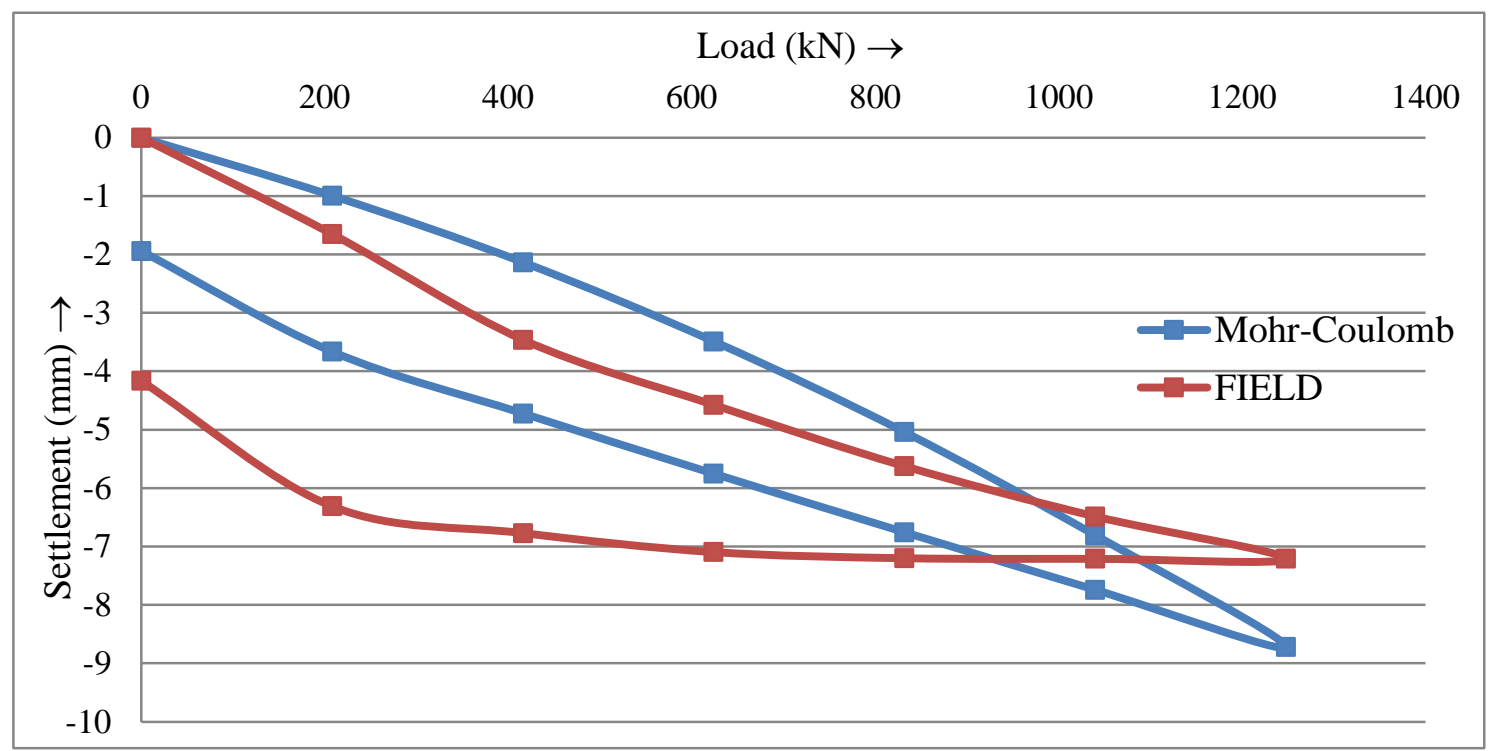

Fig. 4: Load -Settlement Curve corresponding to Field test and FEM (Mohr - Coulomb Soil Model)

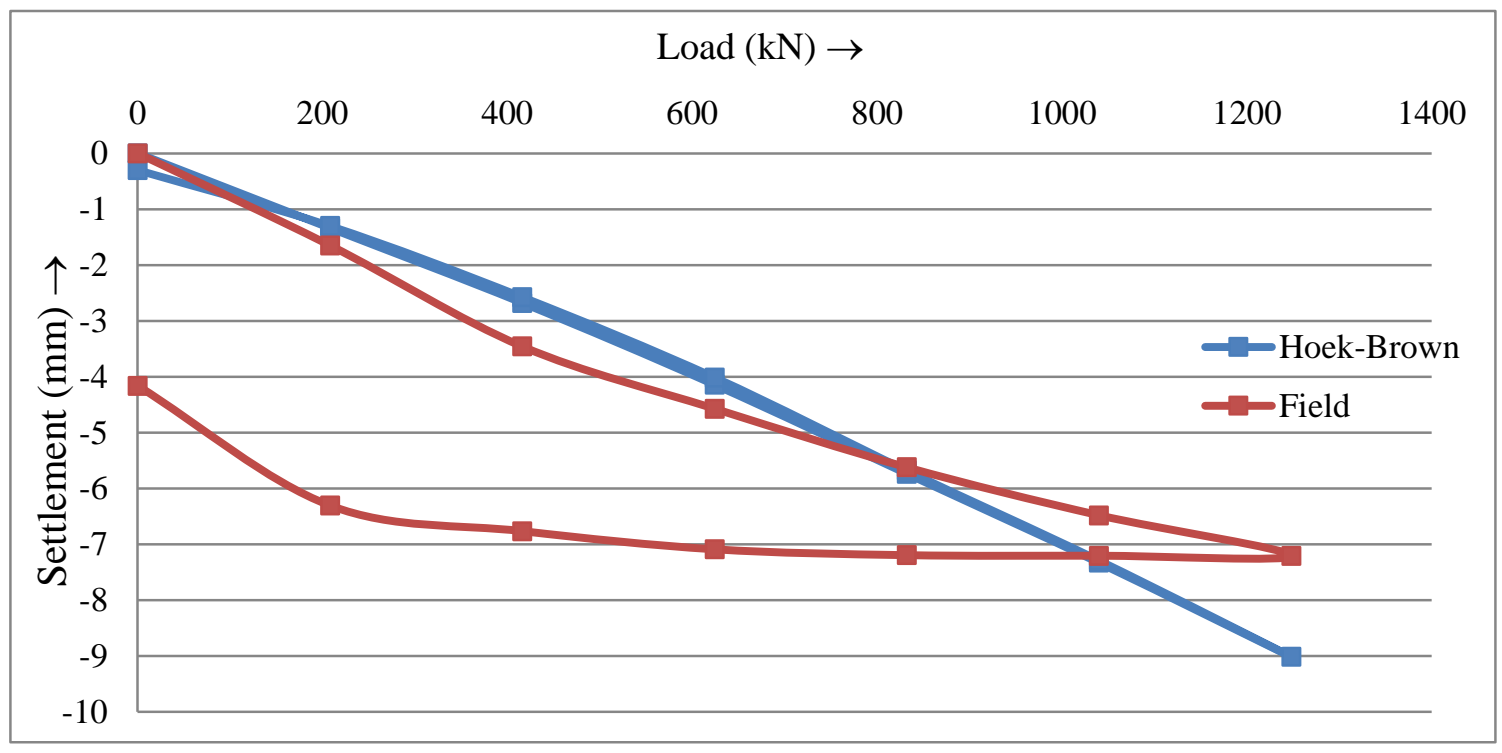

Fig. 5: Load -Settlement Curve corresponding to Field test and FEM (Hoek - Brown Soil Model) 


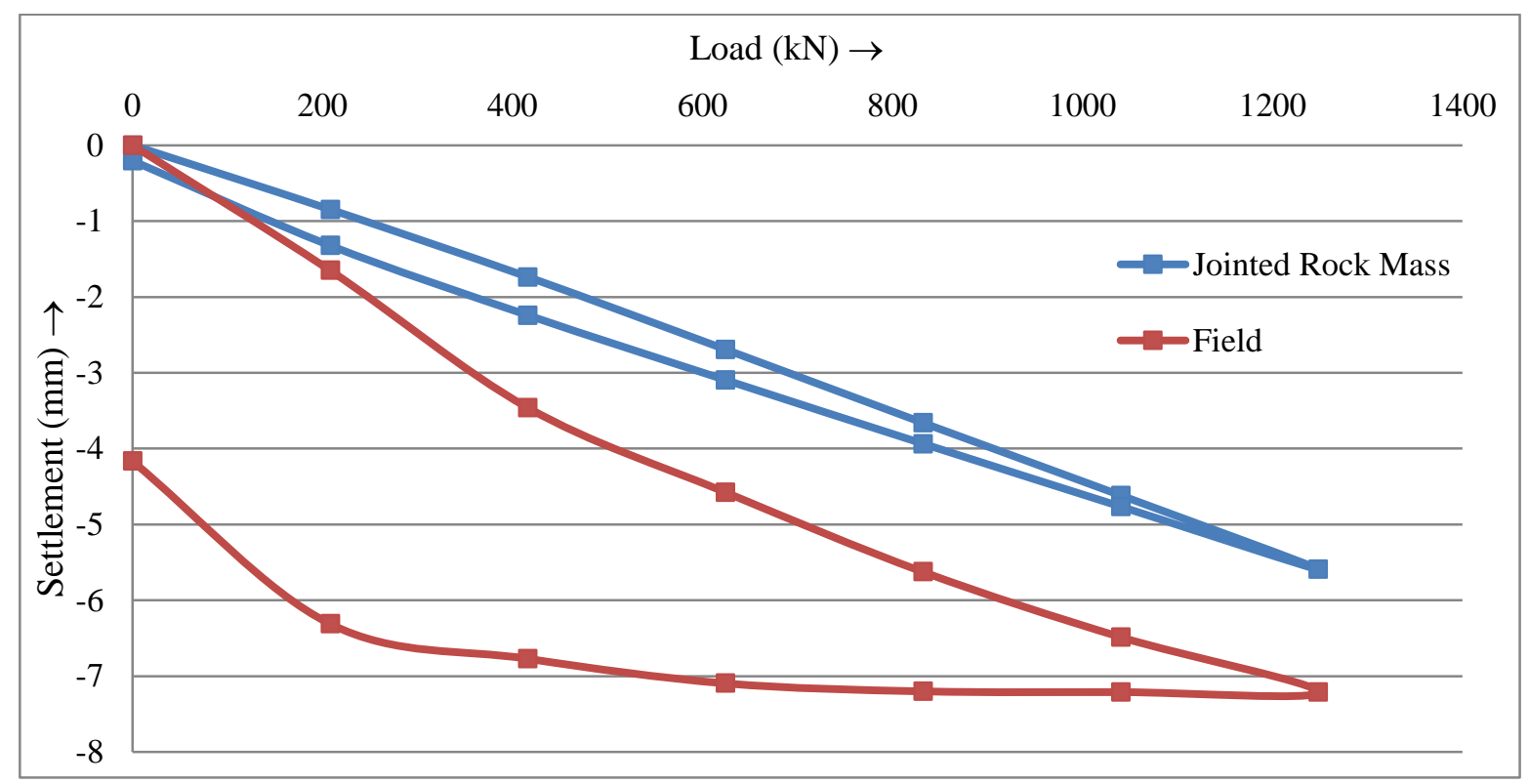

Fig. 6: Load -Settlement Curve corresponding to Field test and FEM (Jointed Rock Mass)

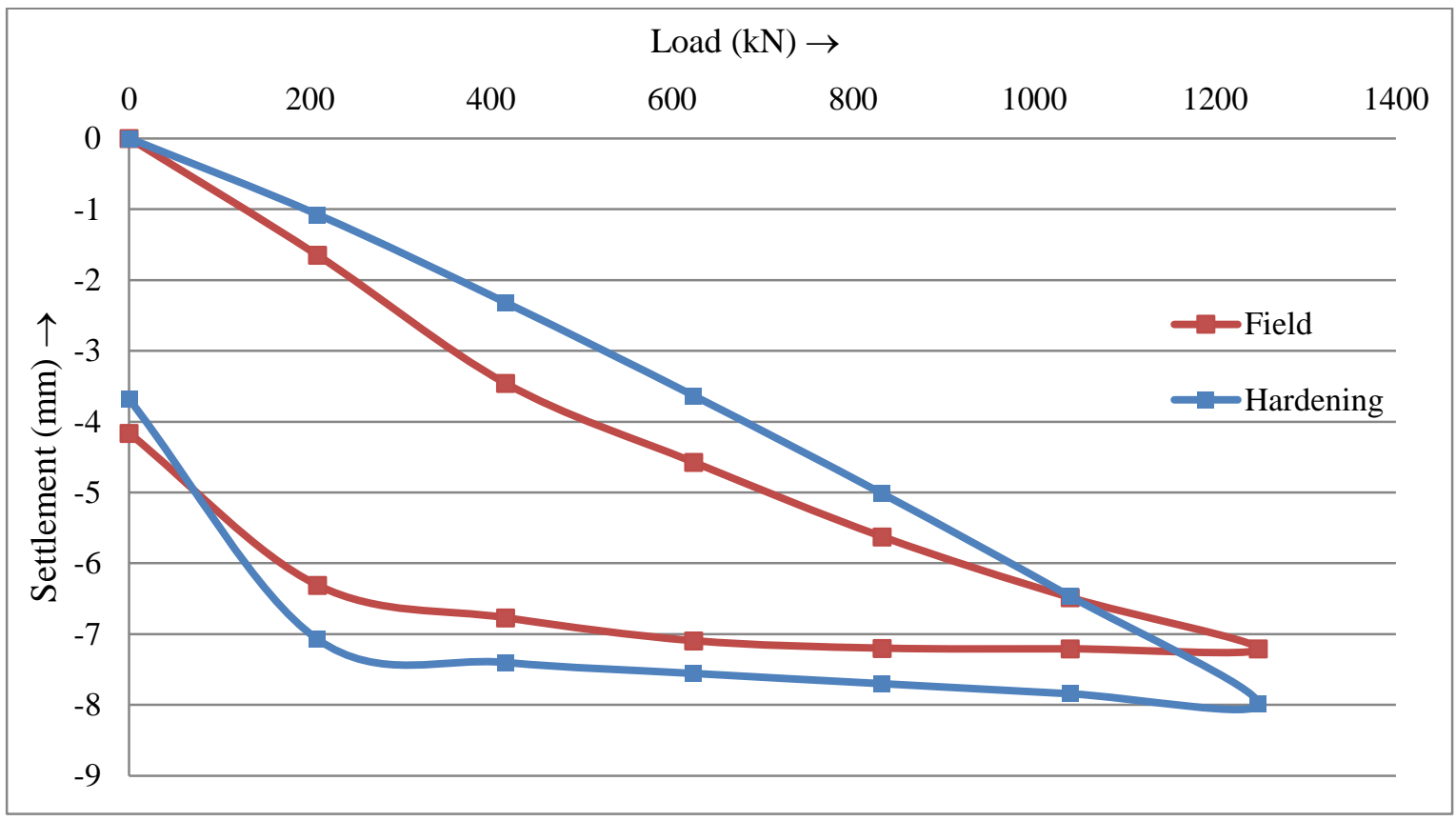

Fig. 7: Load -Settlement Curve corresponding to Field test and FEM (Hardening Soil Model)

The deviation between the fields recorded data and Finite Element simulated data are measured by Root Mean Square Error (RMSE), given by-

$$
R M S E=\sqrt{\frac{1}{n}} \sum_{i=1}^{n}(\text { Data set } 1-\text { Data Set } 2)^{\wedge} 2
$$

Where $\mathrm{n}$ is the total number of observations. 
The values of RMSE corresponding to each soil model has been computed for both the loading as well as unloading phases using equation 1 and has been shown in table no. 4 .

Table 4: RMSE values obtained for Soil Models

\begin{tabular}{|c|c|c|c|}
\hline SI No. & Soil Model & Phase & RMSE \\
\hline \multirow{2}{*}{1} & \multirow{2}{*}{ Mohr-coulomb model } & Loading & 0.932 \\
\hline & & Unloading & 1.75 \\
\hline \multirow{2}{*}{2} & \multirow{2}{*}{ Hoek-Brown model } & Loading & 0.836 \\
\hline & & Unloading & 3.4 \\
\hline \multirow{2}{*}{3} & \multirow{2}{*}{ Jointed Rock model } & Loading & 1.563 \\
\hline & & Unloading & 3.9511 \\
\hline \multirow{2}{*}{4} & \multirow{2}{*}{ Hardening soil model } & Loading & 0.706 \\
\hline & & Unloading & 0.5864 \\
\hline
\end{tabular}

It is observed from Table 4 that for Mohr - Coulomb model, although RMSE is 0.932 in the loading, during unloading the RMSE is 1.75 , which is very high. Therefore, it may be stated that the Mohr - Coulomb model does not reflect the Pare rock mass behaviour well. The unloading behaviour is not all reflected by the Hoek \& Brown Criteria. RMSE (Ref. Table 4) also is found to be 3.4 for unloading stage which is very high. The trend of both the loading and unloading curve is not found to match with the field plate load test data. RMSE also found to be 3.9511 for unloading stage which is very high as per table 4. Good agreement is found to exist between the two. RMSE is also found to be 0.5864 for unloading stage, which shows a very good agreement between the two.

Figure 8 and 9 displays a comparison of the deviations in loading and unloading respectively, in terms of Root Mean Square Error (RMSE), for the four geo-material model, namely Hardening Soil (HS) model, Hoek - Brown model, Mohr Coulomb model and Jointed Rock Mass model.

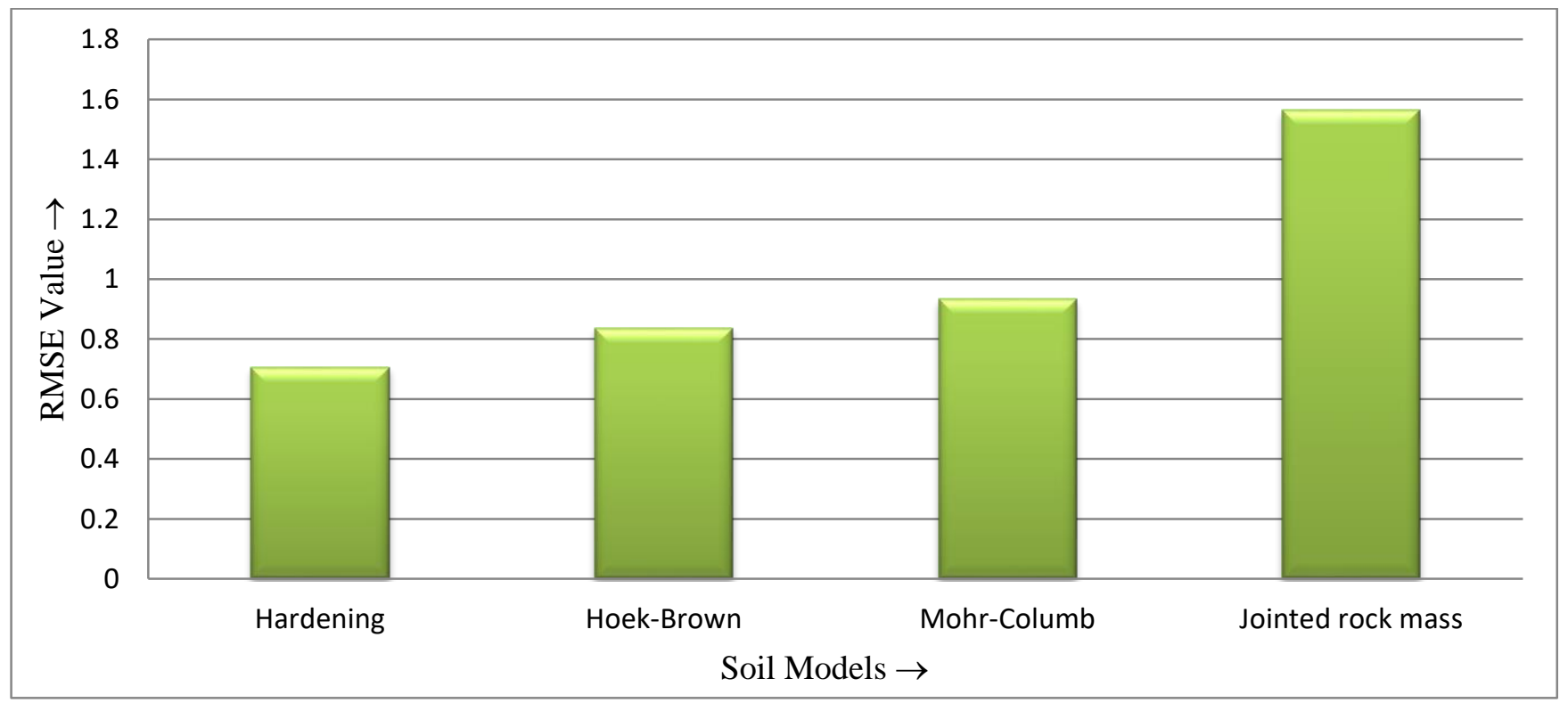

Fig. 8: RMSE values for loading stage corresponding to different soil models 


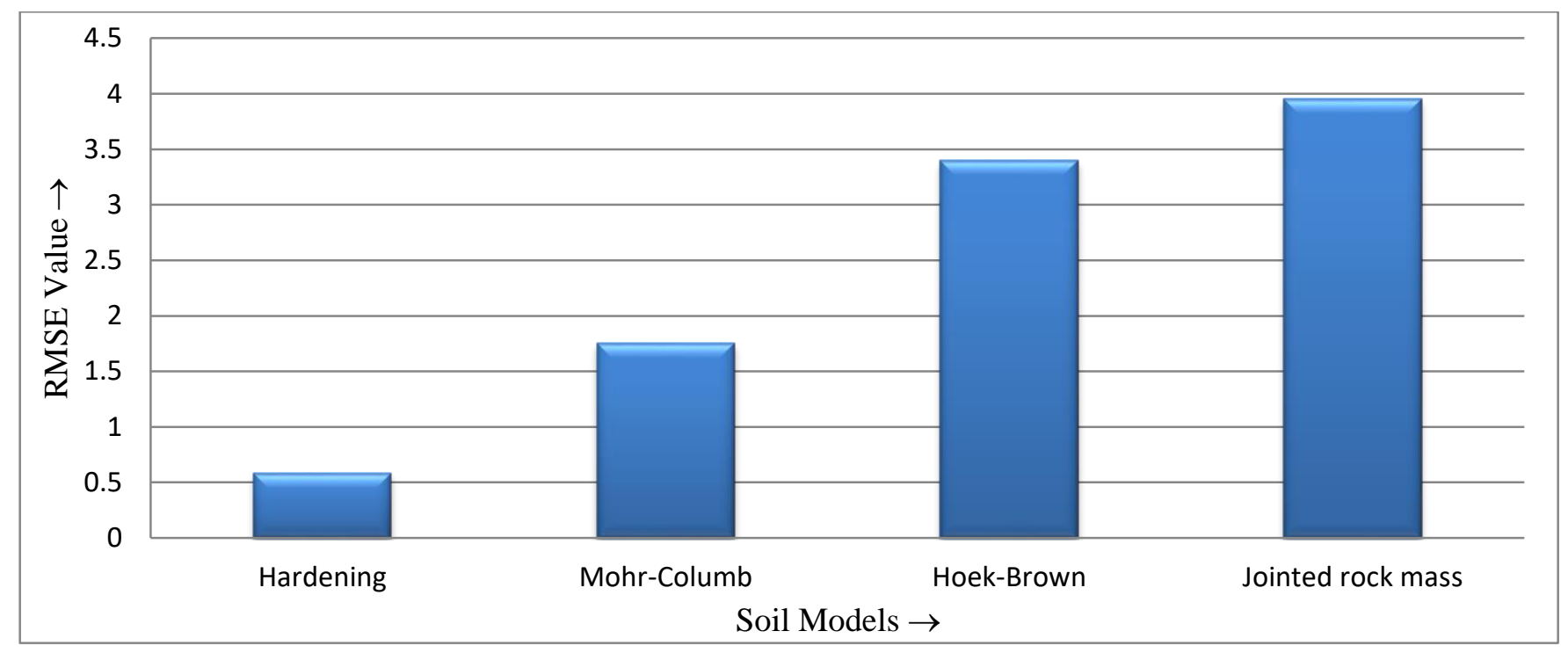

Fig. 9: RMSE values for unloading stage corresponding to different soil models

\section{CONCLUSION}

The case study of load-settlement plot of plate load test at site of Pare, Arunachal Pradesh is simulated with the help of several non-linear finite element processes. The four main models used in this study are Hoek \& Brown soil model, Mohrcoulomb model, Hardening soil model and Jointed rock model. A large number of trials has been taken corresponding to each soil model, but the results of best suitable cases has been presented for each soil model. From the analysis, it has been found that the Hoek \& Brown soil model, Jointed rock model and Mohr-Coulomb model shows linear response whereas the hardening soil model shows non-linear behaviour. Hardening soil model is found to be more usable in the simulation of different soil model. The investigation process by using Hardening soil model is more comparable with respect to other soil models, as soil model contains more soil parameters than Hoek \& Brown soil model and Mohr-coulomb model. Furthermore, the hardening soil model gives the lowest value of "RMSE" in both the loading and unloading case. Also, the trend of loading and unloading curve of Hardening soil model is in good agreement with that of field report. Hence, it can be said that the hardening soil model with the corresponding parameters as presented in table 5 is best suited for Pare Geological Strata.

Table 5: Physical and Mechanical Properties of the Pare Rock Mass as obtained from Simulation

\begin{tabular}{|c|c|c|c|c|c|c|c|c|c|c|c|c|c|c|}
\hline $\begin{array}{c}\gamma_{\text {unsat }}(\mathrm{kN} \\
\left./ \mathrm{m}^{3}\right)\end{array}$ & $\begin{array}{c}\gamma_{\mathrm{sat}} \\
\left(\mathrm{kN} / \mathrm{m}^{3}\right)\end{array}$ & $\mathrm{e}$ & $v$ & $\begin{array}{c}\mathrm{E}_{50} \text { ref } \\
\left(\mathrm{kN} / \mathrm{m}^{2}\right)\end{array}$ & $\begin{array}{c}\mathrm{E}_{\text {oedref }} \\
\left(\mathrm{kN} / \mathrm{m}^{2}\right)\end{array}$ & $\begin{array}{c}\mathrm{E}_{\text {urref }}(\mathrm{k} \\
\left.\mathrm{N} / \mathrm{m}^{2}\right)\end{array}$ & $\begin{array}{c}\mathrm{C}_{\text {ref }} \\
\left(\mathrm{kN} / \mathrm{m}^{2}\right)\end{array}$ & $\Phi$ & $\mathrm{K}_{\text {onc }}$ & $\begin{array}{c}\mathrm{P}_{\text {ref }} \mathrm{N} / \mathrm{m} \\
2\end{array}$ & $\mathrm{Z}_{\text {ref }}$ & $\begin{array}{c}\sigma \mathrm{kN} \\
/ \mathrm{m}^{2}\end{array}$ & $\begin{array}{c}\mathrm{C}^{\prime}{ }_{\text {inc }} \\
\mathrm{kN} / \\
\mathrm{m}^{2}\end{array}$ & \begin{tabular}{c}
$\mathrm{m}_{\mathrm{i}}$ \\
\hline 17.542
\end{tabular} \\
\hline
\end{tabular}

\section{Acknowledgements}

This work is the result of a research project sponsored by NEEPCO Ltd. We sincerely acknowledge NEEPCO Ltd. For providing us the various geological as well as geotechnical data of Pare rock mass, which was necessary for carrying out the present work.

\section{References}

[1] N.S. Isik, R. Ulusay and V. Doyuran, "Deformation modulus of heavily jointed-sheared and blocky greywackes by Pressuremeter tests: numerical, experimental and empirical assessments," Eng. Geol. 101, 2008, pp. 269-282.

[2] A. Kayabasi, C. Gokceoglu and M. Ercanoglu, "Estimating the deformation modulus of rock masses: A comparative 
study,” Int. J. Rock Mech. Min. Sci. 2003, 40, 55-63.

[3] R. Zhang, T. Ren, A. Khan, Y. Teng and J. Zheng, "Back-Calculation of Soil Modulus from PFWD Based on a Viscoelastic Model," Hindawi, Advances in Civil Engineering, 2019.

[4] Singh, B., and Goel, R.K., (2011), "Engineering Rock Mass Classification”. Elsevier Inc. Publication, Amsterdam, pp. 364.

[5] J. G. Grasmick, M. A. Mooney, R. W. Surdahl, M. Voth, and C. Senseney, "Capturing a layer response during the curing of stabilized earthwork using a multiple sensor lightweight deflectometer," Journal of Materials in Civil Engineering, vol. 27, no. 6, Article ID 04014183, 2015.

[6] Kavvadas M.J.,"Modelling the soil behaviour-selection of soil parameters. General report". In: Proceedings of the $2^{\text {nd }}$ International Conference on the Geotechnics of Hard Soils-Soft Rocks . Athens; 12-14 October 1998, vol.2: pp. 14411481.

[7] Consulting Engineering Services, Geological report on pare Hydro Electric Project, Papum pare district, Arunachal Pradesh (Report No.2005025/PE/REP/05 (R0), 2005.

[8] IS 1888: Method of load test on soils, Bureau of Indian Standards, New Delhi (1982). 